\section{Eleutherodactylus jugans (La Selle Dusky Frog). Conservation.}

Category: Conservation. Date of observation: 19 November 2009. Location: Haiti: L'Ouest; ridge crest in Parc Nacional La Visite, southwest of Pic La Visite. Coordinates: 18.34251, -72.2875. Elevation: $1918 \mathrm{~m}$. A single adult of this critically endangered species (IUCN, CR) was found dead (crushed) on a foot trail. No other individuals were found (or heard calling), despite searching under hundreds of rocks and logs in the park. Eleutherodactylus audanti was found un- der rocks and was calling at night. However, the rainy season had ended early and conditions were unusually dry, which may explain reduced frog activity. Accompanied by Elisabeth Rochel, Richard Thomas, and Eladio Fernandez. Thanks to Philippe Bayard and the Audubon Society of Haiti.

S. Blair Hedges, Pennsylvania State University, Department of Biology, 208 Mueller Lab, University Park, Pennsylvania, 16802, USA, sbh1@psu.edu.

Citation: Hedges SB. 2010. Eleutherodactylus jugans (La Selle Dusky Frog). Conservation. Caribbean Herpetology 1:1.

Published online 21 August 2010 